
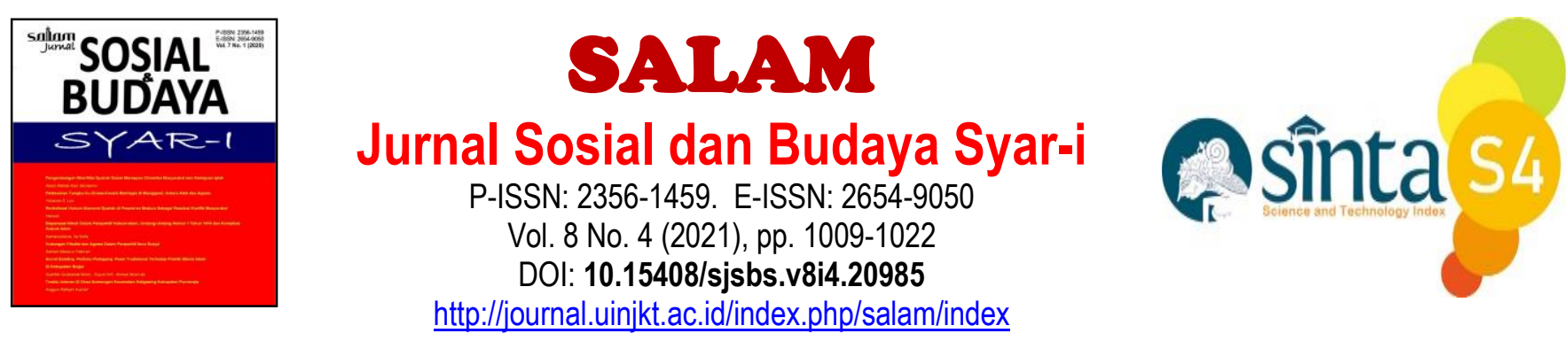

\title{
Penerapan Contempt of Court sebagai Terobosan dalam Membangun Efektivitas Eksekusi Riil dalam Perkara Perdata*
}

\author{
Yoyo Arifardhani ${ }^{1}$ \\ Universitas Pancasila Jakarta \\ do \\ $10.15408 /$ sjsbs.v8i4.20985
}

\begin{abstract}
This study tried to parse the possibility of contempt of court application is a breakthrough to build for effectiveness of real execution of civil cases. The discussion in this study rests on two problem objects, namely; 1) What are the obstacles in the real execution of civil case decisions; and 2) How can a solution be proposed to encourage the effectiveness of the real execution of civil cases. This paper is used to normative legal research so that it rests on the statute approach. The results of this research to indicate that in addition to normative problems in execution arrangements, in practice it is often found that problems occur due to physical resistance from the losing party in the trial. Because of this reason, it is important to apply contempt of court as a legal formulation to create an effective and efficient execution system.
\end{abstract}

Keyword: Contempt of court; Real Execution; Civil Case

\begin{abstract}
Abstrak
Kajian ini mencoba mengurai kemungkinan Penghinaan terhadap Pengadilan yang merupakan terobosan untuk membangun efektivitas eksekusi nyata dalam perkara perdata. Pembahasan dalam penelitian ini bertumpu pada dua objek masalah, yaitu; 1) Apa saja kendala dalam pelaksanaan putusan perkara perdata; dan 2) Bagaimana solusi yang dapat diajukan untuk mendorong efektivitas pelaksanaan perkara perdata yang sebenarnya. Tulisan ini digunakan untuk penelitian hukum normatif sehingga bertumpu pada pendekatan undang-undang. Hasil penelitian ini menunjukkan bahwa selain masalah normatif dalam pengaturan eksekusi, dalam praktiknya sering ditemukan masalah yang terjadi karena adanya perlawanan fisik dari pihak yang kalah dalam persidangan. Oleh karena itu, penting untuk menerapkan Penghinaan terhadap Pengadilan sebagai rumusan hukum untuk menciptakan sistem eksekusi yang efektif dan efisien.

Kata kunci: Penghinaan terhadap Pengadilan; Eksekusi Nyata; Perkara Perdata
\end{abstract}

\footnotetext{
*Received: May 03, 2021, Revision: May 25, 2021, Published: August 5, 2021.

${ }^{1}$ Yoyo Arifardhani adalah dosen Universitas Pancasila Jakarta. Email: arifardhaniyoyo@gmail.com
} 


\section{Yoyo Arifardhani}

\section{A. PENDAHULUAN}

Pengajuan setiap gugatan perkara perdata di muka pengadilan tentu bertujuan untuk menyelesaikan permasalahan atau sengketa melalui putusan hakim. Dalam hal ini, setiap penggugat akan berangkat dari harapan agar apa yang menjadi petitum dalam gugatan tersebut dikabulkan. Sebaliknya, pihak tergugat akan senantiasa berharap bahwa gugatan itu ditolak bahkan tidak diterima oleh pengadilan.

Hanya saja, penyelesaian perkara perdata tidak berhenti sampai pada tahap perkara itu diputus dan mempunyai kekuatan hukum tetap (incracht) saja, akan tetapi juga harus diikuti oleh eksekusi putusan tersebut secara efektif dan tertib sebagaimana mestinya. Terutama dalam hal putusan tersebut bersifat menghukum, yaitu putusan yang mengandung perintah kepada suatu pihak untuk melaksanakan perbuatan.

Pada faktanya dalam perkara perdata, pelaksanaan putusan pengadilan diperintahkan untuk dilakukan kepada pihak yang dikalahkan. Akan tetapi Sebagian besar pihak yang kalah tidak mau menjalankan putusan secara sukarela. Sehingga perlu dilakukan kepada pihak yang memenangkan perkara untuk mengajukan permohonan eksekusi terhadap pengadilan, yang tentunya akan menghabiskan waktu, tenaga dan biaya untuk yang sekian kalinya.

Tidak sampai di situ, permasalahan selanjutnya adalah fakta bahwa dikabulkannya permohonan eksekusi pun tidak memberikan jaminan bahwa perintah putusan tersebut akan dilaksanakan oleh Tergugat/Termohon eksekusi. Dalam beberapa kasus tetap saja pihak Tergugat/Termohon Eksekusi bahkan melakukan perlawanan secara fisik agar supaya eksekusi tidak dapat dilaksanakan/ gagal eksekusi dilakukan. Tak pelak, segala daya yang dikerahkan dalam proses memenangkan perkara akan terasa sia-sia, jika pada akhirnya putusan pengadilan tidak dapat dieksekusi secara efektif.

Pengabaian terhadap putusan pengadilan tentu menjadi keresahan tersendiri bagi para pencari keadilan. Untuk itu, diperlukan pengaturan yang lebih tegas agar putusan pengadilan benar-benar dilaksanakan sebagaimana mestinya. Salah satu diantaranya yang akan menjadi topik dalam tulisan ini adalah kemungkinan penerapan delik Contempt of court bagi pihak yang secara sengaja mengabaikan perintah putusan pengadilan, khususnya pengadilan perdata.

Berdasarkan ulasan di atas, permasalahan yang akan diteliti dalam tulisan ini adalah: 1). Kendala-kendala apakah yang ada dalam proses eksekusi riil putusan perkara perdata? 2). Bagaimana jalan keluar yang dapat diajukan untuk mendorong efektivitas eksekusi riil perkara perdata yang telah berkekuatan hukum tetap?

\section{B. METODE PENELITIAN}

Penelitian dalam dua permasalahan tersebut di atas dilakukan dengan menggunakan metode yuridis normatif dengan cara menggunakan pendekatan perundang-undangan (statute approach). Dalam pembuatan paper ini, bahan-bahan yang terkumpul akan disistemisasi dan dianalisis secara deskriptif kualitatif berdasarkan 
pada prinsip-prinsip atau teori-teori hukum yang terdapat dalam dunia ilmu hukum untuk menghasilkan jawaban dan pemecahan terhadap persoalan-persoalan dalam rumusan masalah

\section{HASIL TEMUAN DAN PEMBAHASAN}

\section{Pengaturan Eksekusi Putusan Pengadilan Perdata}

Pengertian eksekusi, menurut M. Yahya Harahap, merupakan suatu pelaksanaan secara paksa putusan pengadilan dengan bantuan kekuatan umum apabila pihak yang kalah (tereksekusi atau pihak tergugat) tidak mau menjalankan secara sukarela. ${ }^{2}$

Dalam definisi yang hampir serupa, Abdul Manan menjelaskan bahwa eksekusi merupakan suatu hal yang berkaitan dengan upaya menjalankan putusan pengadilan yang sudah berkekuatan tetap. Secara lebih spesifik, Abdul Manan mengungkapkan pendapatnya sebagai berikut:

"Putusan pengadilan yang dieksekusi adalah putusan yang mengandung perintah kepada salah satu pihak untuk membayar sejumlah uang atau juga pelaksanaan putusan hakim yang memerintahkan pengosongan benda tetap, sedangkan pihak yang kalah tidak mau melaksanakan putusan itu secara sukarela sehingga memerlukan upaya paksa dari pengadilan untuk melaksanakannya" ${ }^{3}$

Sementara itu, Wildan Suyuthi menjelaskan bahwa menjalankan eksekusi putusan perdata berarti menjalankan putusan dalam perkara perdata secara paksa sesuai dengan peraturan perundang-undangan yang berlaku karena pihak tereksekusi tidak bersedia melaksanakan secara sukarela. ${ }^{4}$

Berdasarkan pada pengertian sebagaimana dikemukakan oleh para ahli perdata di atas, maka dapat ditarik kesimpulan bahwa pengertian eksekusi merupakan tindakan paksa yang dilakukan Pengadilan Negeri pada perkara perdata terhadap pihak yang kalah dalam perkara menjalankan Amar Putusan Pengadilan. Eksekusi putusan ini diatur dalam ketentuan dalam Pasal 196 Herzien Inlandsch Reglement (HIR):

"Jika pihak yang dikalahkan tidak mau atau lalai untuk memenuhi isi keputusan itu dengan damai, maka pihak yang menang memasukkan permintaan, baik dengan lisan, maupun dengan surat, kepada ketua, pengadilan negeri yang tersebut pada ayat pertama pasal 195, buat menjalankan keputusan itu Ketua menyuruh memanggil pihak yang dikalahkan itu serta memperingatkan, supaya ia memenuhi keputusan itu di dalam tempo yang ditentukan oleh ketua, yang selama-lamanya delapan hari."

Pada prinsipnya permohonan eksekusi hanya dapat dilakukan terhadap semua putusan pengadilan dalam perkara yang berkekuatan hukum tetap (incracth). Putusan incracht artinya; putusan pengadilan negeri yang diterima oleh kedua belah pihak yang

${ }^{2}$ M. Yahya Harahap, Ruang Lingkup Eksekusi Bidang Perdata, PT. Gramedia, 1989, Jakarta, hlm. 20.

${ }^{3}$ Abdul Manan, hlm. 5

${ }^{4}$ Wildan Suyuthi, 2005, Sekitar Acara dan Hukum Perdata Agama, dalam Adityo Wahyu Wikanto, Safrudin Yudowibowo, Harjono, "Eksekusi Riil dalam Perkara Perdata Tentang Pengosongan Tanah dan Bangunan Rumah", Jurnal Verstek, Vol.2, No. 2, 2014, hlm. 4. 


\section{Yoyo Arifardhani}

berperkara, putusan perdamaian, putusan verstek yang terhadapnya tidak diajukan verzet atau banding, putusan pengadilan tinggi yang diterima baik oleh kedua belah pihak dan tidak dimohonkan kasasi, dan putusan Mahkamah Agung dalam hal kasasi. Selain itu, penting juga dijelaskan bahwa menurut sifatnya putusan itu dapat diklasifikasikan menjadi 3 (tiga) macam, yaitu: 1) putusan penetapan, yaitu putusan yang hanya sekedar menerangkan atau menetapkan suatu keadaan saja, 2) putusan constitutif, yaitu putusan yang menciptakan atau menghapus kan suatu keadaan, tidak perlu dilaksanakan; 3) putusan menghukum, yaitu putusan yang berisi penghukuman untuk melakukan sesuatu atau tidak melakukan akan sesuatu.

Terhadap dua putusan yang disebutkan di awal, yakni putusan declaratoir dan putusan constitutief tidak memerlukan eksekusi. Berbeda halnya dengan putusan menghukum/comdemnatoir yang berisi penghukuman. Maka pihak yang kalah dihukum untuk melakukan sesuatu.

Berkaitan dengan hal tersebut, Sudikno Mertokusumo menjelaskan bahwa apabila ditinjau dari sasaran yang hendak dicapai oleh hubungan hukum yang tercantum berdasarkan putusan pengadilan yang bersifat hukuman/condemnatoir, maka jenis eksekusi dapat diklasifikasikan menjadi 3 (tiga) bentuk yaitu sebagai berikut: ${ }^{5}$

Pertama; Melaksanakan suatu perbuatan. Amar suatu putusan pengadilan perdata dapat berupa perintah atau hukuman untuk melaksanakan suatu perbuatan tertentu. Contohnya, menyerahkan barang, pengosongan sebidang tanah atau tanah, dan lain sebagainya. Dalam konteks ini, jika seseorang tidak melakukan perbuatan sebagaimana diperintah atau di hukum oleh hakim melalui putusannya, maka pihak yang dimenangkan dalam putusan hakim dapat meminta kepada ketua pengadilan negeri, baik secara lisan maupun tulisan meminta atau mengajukan permohonan agar kepentingan yang menjadi haknya supaya segera dipenuhi oleh pihak yang dikalahkan dalam putusan hakim tersebut. ${ }^{6}$

Kedua; Eksekusi riil. Eksekusi riil dapat diartikan sebagai “tindakan nyata/riil” sebagai tindak lanjut dari perintah putusan pengadilan. Contohnya, menyerahkan barang/pembongkaran/menghentikan suatu perbuatan tertentu, dan lain-lain sebagainya. Eksekusi riil ini dapat dilakukan langsung dengan perbuatan nyata, sesuai dengan amar putusan tanpa memerlukan proses lelang. ${ }^{7}$

Ketiga; Eksekusi membayar sejumlah uang. Amar putusan pengadilan perdata adakalanya memerintahkan agar pihak tertentu untuk membayar sejumlah uang ganti rugi. Terhadap putusan yang demikian, maka eksekusi hanya dijalankan dengan proses pelelangan terlebih dahulu. Hal ini tentu kebalikannya dari eksekusi riil di mana eksekusi dapat dilakukan dengan perbuatan nyata, tanpa didahului oleh proses pelelangan. Hal ini disebabkan nilai yang akan dieksekusi itu bernilai uang. ${ }^{8}$

${ }^{5}$ Sudikno Mertokusumo. 1998. Hukum Acara Perdata Indonesia, ibid, hlm. 10.

${ }^{6}$ Lihat pasal 225 Herzien Inlandsch Reglement

${ }^{7}$ Lihat Pasal 1033 Wetboek op de Burgerlijke Rechtvordering yaitu hukum acara perdata dan pidana yang berlaku untuk golongan Eropa di jaman penjajahan.

${ }^{8}$ Lihat Pasal 196 Herzien Inlandsch Reglement 
Dalam konteks sistem hukum Indonesia, ketentuan perihal eksekusi diatur dalam ketentuan HIR atau RBG, yaitu pada Pasal 195 sampai dengan Pasal 224 HIR atau Pasal 206 s.d. 258 RBG. Namun sebagian dari pasal-pasal tersebut sudah tidak berlaku lagi, seperti Pasal 209 sampai dengan 223 HIR, dan Pasal 242 sampai dengan Pasal 257 RBG yang mengatur tentang sandera (gijzeling). Yang masih berlaku efektif adalah Pasal 195 sampai dengan Pasal 208 dan Pasal 224 HIR, atau Pasal 206 sampai dengan Pasal 240 dan Pasal 258 RBG.

Dalam hal pihak yang kalah dalam putusan Hakim tidak mau melaksanakan putusan pengadilan, maka pihak yang menang dapat mengajukan permohonan eksekusi kepada Pengadilan Tingkat Pertama (Pengadilan Negeri dan Pengadilan Agama). ${ }^{9}$ Untuk selanjutnya, ketua pengadilan negeri setempat dapat memanggil dan memperingatkan (anmaning) agar pihak yang bersangkutan melaksanakan putusan yang dimaksud.

Jika setelah jangka waktu yang telah ditetapkan, pihak yang kalah perkara juga tidak dengan sukarela melaksanakan isi putusan, maka sejak saat itu pihak yang menang perkara dapat mengajukan permohonan eksekusi kepada ketua pengadilan negeri untuk menindaklanjuti putusan perdata, sebagaimana yang ditetapkan dalam Pasal 197 HIR;

"Jika sudah lewat waktu yang ditentukan itu, sedangkan orang yang kalah itu belum juga memenuhi keputusan itu, atau jika orang itu, sesudah dipanggil dengan sah, tidak juga menghadap, maka ketua, karena jabatannya, akan memberi perintah dengan surat, supaya disita sekian barang bergerak dan jika yang demikian tidak ada atau ternyata tiada cukup, sekian barang tak bergerak kepunyaan orang yang kalah itu, sampai dianggap cukup menjadi pengganti jumlah uang tersebut dalam keputusan itu dan semua biaya untuk melaksanakan keputusan itu".

Proses Peringatan (aamaning) tersebut dilakukan dalam pemeriksaan yang dihadiri oleh ketua pengadilan negeri setempat, panitera, dan pihak-pihak dalam perkara yang hendak dieksekusi. Dalam persidangan tersebut, ketua pengadilan memperingatkan termohon eksekusi untuk melaksanakan perintah putusan dalam jangka waktu 8 (delapan) hari. Semua peristiwa yang terjadi dalam persidangan pemberian peringatan tersebut akan dicatat oleh panitera dalam berita acara, sebagai bukti autentik sidang pemberian peringatan kepada termohon. Berita acara peringatan tersebut penting untuk mendukung dan menjadi sumber landasan hukum bagi keabsahan perintah eksekusi selanjutnya.

Proses eksekusi pengosongan tidak selalu harus diletakkan sita eksekusi, dalam perkara tersebut eksekusi pengosongan dapat langsung dilaksanakan proses pengosongan tanpa melalui penyitaan. Bagi putusan yang memerintahkan untuk melakukan pengosongan (eksekusi riil) maka hari dan tanggal pelaksanaan

${ }_{9}^{9}$ Pasal 195 ayat (1) HIR atau Pasal 206 ayat (1) Rechtreglement voor de Buitengewesten (RBg). RBg adalah Reglemen Hukum Daerah Seberang (di luar jawa Madura)], yaitu hukum acara yang berlaku di persidangan perkara perdata maupun pidana di pengadilan di luar Jawa dan Madura di jaman Hindia Belanda. Tercantum dalam Staatblad 1927 No. 227. 


\section{Yoyo Arifardhani}

pengosongan ditetapkan oleh Ketua Pengadilan Negeri, setelah dilakukan rapat koordinasi dengan aparat keamanan.

Yahya Harahap berpendapat bahwa kewenangan eksekusi timbul manakala termohon tidak bersedia menjalankan putusan secara sukarela. pihak termohon dianggap tidak mau menjalankan putusan secara sukarela sejak tanggal peringatan (aanmaning) dilampaui dan sejak saat itulah definitif upaya eksekusi berlaku. Persoalannya, adalah fakta sering terjadi bahwa Hukum Acara Perdata nyatanya tidak mengatur kapan sidang aanmaning harus dilaksanakan. Padahal jika mengacu pada ketentuan Pasal 196 HIR, pelaksanaan aanmaning menjadi prasyarat utama melakukan putusan eksekusi. Akibatnya, terbuka kemungkinan pelaksanaan eksekusi yang berlarut-larut karena tidak ada batas waktu yang baku yang harus diikuti oleh ketua pengadilan.

\section{Kendala-Kendala dalam Eksekusi Riil Perkara Perdata}

Pada faktanya bahwa proses eksekusi putusan, terutama dalam perkara perdata merupakan suatu proses yang cukup melelahkan pihak-pihak yang berperkara, selain menyita waktu, energi, biaya, tenaga juga pikiran. Suatu putusan tentu tidak ada artinya jika hasilnya sebatas keputusan hitam diatas putih saja atau tidak dapat dilaksanakan lantaran putusan tersebut diabaikan oleh pihak yang kalah dalam perkara. Karena itu, kemenangan dalam perkara perdata harus ditindaklanjuti dengan proses yang panjang untuk bisa mendapatkan hasil secara nyata/kongkret. Hal ini terjadi karena dalam praktiknya pelaksanaan eksekusi tidak jarang menemui banyak kendala. Terutama disebabkan oleh pihak yang kalah/ termohon umumnya sulit untuk menerima kekalahan dan cenderung untuk menolak putusan yang sudah punya kekuatan hukum tetap dengan berbagai macam cara. ${ }^{10}$

Mengeksekusi obyek sengketa dengan cara memaksa pihak tereksekusi/termohon untuk mengosongkan atau menyerahkan obyek sengketa kepada pihak pemohon eksekusi. Apabila tereksekusi/ termohon tetap bertahan diatas obyek sengketa dan tidak mau menyerahkan kepada pemohon eksekusi, maka hal itu dapat mengakibatkan ditangguhnya pelaksanaan eksekusi. Sebab salah satu kendala atau hambatan terhadap pelaksanaan eksekusi terjadi penundaan di pengadilan adalah menyangkut keamanan, dimana pihak yang tereksekusi/ termohon mengadakan perlawanan.

Seringkali Ketua Pengadilan harus "turun tangan" untuk memperlancar jalannya eksekusi. Pelaksanaan eksekusi dalam perkara perdata memiliki suatu resiko yang tinggi sebab proses mengeksekusi obyek perkara adalah merupakan suatu upaya paksa yang dilakukan oleh pihak pemohon eksekusi terhadap termohon eksekusi agar menjalankan sebagaimana perintah putusan pengadilan.

${ }^{10}$ Wildan Suyuti, 2004, Sita Eksekusi; Praktek Kejurusitaan Pengadilan, PT. Tatanusa, Jakarta, hlm. 60. 
Pendapat Yahya Harahap; proses Eksekusi pada dasarnya tidak dapat ditunda kecuali dengan alasan-alasan khusus yang sifat eksepsional dan sementara, yaitu sebagai berikut: ${ }^{11}$

Pertama; Alasan Kemanusiaan. Penundaan eksekusi dengan alasan kemanusiaan hanya bersifat sementara, yang biasanya terbatas dalam jangka waktu 3 hingga 6 bulan atau dalam jangka waktu tertentu yang dianggap patut menurut penalaran yang wajar. Hal ini dimaksudkan agar termohon diberikan kelonggaran untuk dapat melaksanakan perintah putusan pengadilan.

Kedua; Adanya Perlawanan Dari Pihak Ketiga (derden verzet). Dalam hal ada perlawanan dari pihak ketiga, maka eksekusi dapat ditangguhkan untuk sementara. Hal ini berdasarkan ketentuan pasal 195 HIR yang menjelaskan bahwa pihak ketiga diberi hak mengajukan perlawanan terhadap proses eksekusi atas dasar adanya hak milik, dimana obyek eksekusi merupakan milik pihak yang mengajukan perlawanan dan eksekusi dilarang dilaksanakan terhadap milik pihak ketiga.

Ketiga; Obyek Masih Dalam Pemeriksaan Perkara Lain. Penundaan eksekusi juga dapat terjadi dikarenakan obyek yang akan dieksekusi masih menjadi obyek pemeriksaan dalam perkara lain. Eksekusi harus menunggu hasil dari pemeriksaan.

Keempat; Adanya Permohonan PK. Pasal 66 UU No. 14 tahun 1985 tentang Mahkamah Agung, sebenarnya disebutkan bahwa adanya permohonan PK tidak menghambat eksekusi putusan Namun dalam praktiknya, keberadaan permohonan PK dapat dijadikan alasan oleh pengadilan untuk melakukan penundaan eksekusi.

Perlawanan oleh pihak yang kalah maupun pihak ketiga tidak dilakukan melalui mekanisme hukum yang ada. Tidak jarang perlawanan dilakukan secara fisik/ kekerasan. Dalam hal ini laporan LeIP menjelaskan bentuk-bentuk perlawanan secara fisik, antara lain; (a) mengunci rapat tanah objek eksekusi; (b) menempatkan preman untuk menduduki tanah objek eksekusi; (c) mengerahkan massa untuk berdemo di tanah objek eksekusi; (d) melakukan tindak kekerasan di tanah objek eksekusi; (e) memasang plang nama atau organisasi massa (ormas) atau organisasi keagamaan, membangun posko ormas atau organisasi keagamaan, mengadakan kegiatan keagamaan di atas tanah objek eksekusi untuk membenturkan ormas atau organisasi keagamaan dengan petugas eksekusi; (f) melaporkan pimpinan pengadilan dan petugas eksekusi ke berbagai instansi, baik Pengadilan Tinggi, Mahkamah Agung, dan Ombudsman untuk mengganggu kenyamanan mereka dalam bekerja. ${ }^{12}$

Dalam praktik juga ditemukan kendala-kendala seperti masalah, seperti obyek tereksekusi tidak dapat dijangkau oleh kendaraan, biaya eksekusi cukup mahal. Sebagaimana tertuang dalam data sepanjang 2012 hingga 2018 pada lima belas pengadilan negeri di Indonesia menunjukkan belum semua permohonan eksekusi

${ }^{11}$ Yahya Harahap, Op.Cit., hlm. 284-306.

12 Alfeus Jebabun dkk, Initial AssesmentProblems of court decision enforcment system in indonesia", Lembaga Kajian \& Advokasi Independensi Peradilan, Jakarta, 2018, hlm.37. 


\section{Yoyo Arifardhani}

sengketa perdata yang masuk pengadilan selesai dilaksanakan. ${ }^{13}$ Adapun yang menjadi faktor penghambat penyelesaian perkara tersebut adalah sulitnya proses eksekusi putusan, lamanya proses penyelesaian perkara, dan tingginya biaya berperkara. ${ }^{14}$

Problematika juga terjadi pada seputar proses eksekusi adakalanya muncul karena amar putusan tidak jelas. Biasanya, Ketua Pengadilan Negeri melakukan penelitian terhadap pertimbangan-pertimbangan hakim dalam putusan tersebut. Hal ini dikarenakan amar dan pertimbangan putusan merupakan satu kesatuan yang tidak terpisah, sehingga jika pertimbangan juga tidak jelas, maka Ketua Pengadilan Negeri dapat menanyakan pada Majelis Hakim yang bersangkutan. Ketua pengadilan negeri dapat mengeluarkan penetapan non-eksekutabel. ${ }^{15}$ Sebagai contoh, pada perkara tanah yang luas tanahnya melebihi yang tercantum dalam amar putusan, maka yang dilaksanakan hanya seluas amar putusan, dan untuk tanah kurang dari amar putusan maka eksekusi dilaksanakan apa adanya dan kekurangannya dicatat dalam berita acara eksekusi.

Permasalahan lainnya adalah mengenai ketiadaan dasar hukum yang mengatur secara tegas yang mengatur siapa yang seharusnya dibebankan membayar biaya eksekusi dan kapan biaya eksekusi dibayarkan. Pasal 197 HIR tidak menjelaskan siapa pihak yang dibebankan membayar panjar eksekusi. Namun jika mengacu pada praktiknya biaya ini dibebankan kepada pemohon. Hal ini menjadi beban tersendiri bagi pihak yang menang dalam perkara untuk mengajukan eksekusi ke pengadilan. Terlebih lagi untuk perkara-perkara yang dapat diajukan dengan mekanisme gugatan sederhana. ${ }^{16}$

Berdasarkan pada Pasal 31 Perma No. 2 Tahun 2015, eksekusi gugatan sederhana dilakukan secara sukarela. Namun, jika putusan tidak dilaksanakan secara sukarela, maka putusan dilaksanakan berdasarkan ketentuan hukum acara perdata yang berlaku ${ }^{17}$, yaitu sebagaimana untuk gugatan biasa yang diatur dalam HIR untuk gugatan biasa. Praktisnya, putusan terhadap gugatan sederhana dapat saja secara sengaja diabaikan oleh pihak yang kalah agar dapat mengulur-ngulur waktu dilaksanakannya putusan. Terlebih lagi, untuk mengajukan permohonan eksekusi akan menjadi pertimbangan tersendiri bagi penggugat terutama jika obyek yang menjadi sengketa bernilai kecil.

${ }^{13}$ Tim Riset dan Publikasi, "Menuju Pelaksanaan Eksekusi Putusan Perdata yang Efektif - Analisis Katadata" artikel diunduh

dari $\quad$ https://katadata.co.id/timrisetdanpublikasi/analisisdata/5e9a57af9a822/menuju-pelaksanaaneksekusi-putusan-perdata-yang-efektif, Pukul 10.57 WIB, 13 April 2021.

${ }^{14}$ Ibid.

15 Yahya Harahap, Hukum Acara Perdata Tentang Tentang Gugatan, Persidangan, Penyitaan, Pembuktian, Dan Putusan Pengadilan, Cetakan Ketiga, Jakarta, 2005.

${ }^{16}$ Gugatan sederhana adalah tata cara pemeriksaan di persidangan terhadap gugatan perdata cedera janji dan/atau perbuatan melawan hukum dengan nilai gugatan materil paling banyak Rp 200.000.000 dan diselesaikan dengan tata cara dan pembuktian sederhana, lihat Menurut Pasal 3 ayat (1) Peraturan Mahkamah Agung No. 2 Tahun 2015 Tentang Tata Cara Penyelesaian Gugatan Sederhana.

${ }^{17} \mathrm{Ibid}$, Pasal 3 ayat (2) dan (3). 
Belum lagi menyadari bahwa dalam praktiknya terkadang eksekusi putusan tidak berjalan dengan baik karena adanya perlawanan oleh pihak tereksekusi dan mendapat dukungan dari masyarakat setempat. Selain itu, persoalan tidak dipatuhinya putusan pengadilan bukan hanya terletak pada pengaturan yang tidak tegas atau tidak adanya aturan pelaksanaan mengenai upaya paksa, tetapi terletak permasalahan pada struktur kelembagaan dalam penegakan hukum perdata.

Hukum acara perdata tidak secara tegas mengatur lembaga eksekutor atau lembaga otoritatif atas pelaksanaan putusan pengadilan perdata. Pada konteks pidana, para korban baik individu, masyarakat ataupun badan hukum yang dirugikan atas akibat terjadinya suatu tindak pidana oleh pelaku memiliki hak yang jelas untuk mendorong kejaksaan melaksanakan putusan pengadilan dan di pihak kejaksaan juga bisa menggunakan upaya paksa berupa ancaman pemidanaan terhadap pelaku yang menghalang-halangi atau tidak patuh atas pelaksanaan putusan.

Hal itulah yang menjadi kekurangan dalam sistem hukum perdata. Hukum acara perdata hanya memberikan hak kepada pihak yang menang untuk mengajukan permohonan eksekusi, sedangkan proses eksekusi seringkali tidak dapat dilaksanakan oleh karena adanya perlawanan dari pihak yang kalah di antaranya menggerakkan massa agar membuat eksekusi tidak dapat dilakukan/dilaksanakan. Terlebih lagi untuk lembaga, badan, instansi yang memiliki kewenangan semi peradilan seperti, Badan Penyelesaian Sengketa Konsumen (BPSK) misalnya, yang memang secara kelembagaan putusannya tidak memiliki kekuatan eksekutorial.

Dalam hal ini, pemohon harus melakukan usaha ekstra untuk mendapatkan keadilannya. Dengan kata lain, tidak ada jaminan bahwa setelah diputusnya permohonan eksekusi perintah putusan pengadilan itu akan dilaksanakan oleh termohon eksekusi. Perbuatan pengabaian terhadap putusan pengadilan jelas mencederai pihak yang telah menang dalam perkara melalui putusan hakim, tetapi juga mencederai suatu proses keadilan secara luas.

Kendala atau hambatan dalam pelaksanaan proses eksekusi putusan pengadilan itu tentu akan menimbulkan keresahan dan perasaan pesimistis untuk menempuh penyelesaian perkara perdata di pengadilan, kendala eksekusi memberikan suatu gambaran pada kita bahwa asas peradilan sederhana, cepat dan biaya ringan makin hari makin tidak memberi harapan kepada para pencari keadilan, bahkan semakin mendekati adanya ketidakpastian.

Pada konteks hukum acara perdata terlihat bahwa kehadiran negara sangat minim ketika terjadi eksekusi putusan. Padahal, pelaksanaan putusan sendiri seringkali berkaitan dengan "adu kekuatan" antara masyarakat sipil. Untuk itu, penting untuk menghadirkan lembaga eksekutorial yang jelas dalam konteks hukum perdata guna memberikan keadilan bagi para pencari keadilan. 


\section{Penerapan Delik Contempt of Court Sebagai Solusi Mendorong Efektivitas Eksekusi Putusan}

Pengertian contempt of court umumnya dipahami sebagai perbuatan yang melanggar, menghina, dan memandang rendah lembaga pengadilan. Hal ini merujuk pada pengertian contempt of court dalam Black's Law Dictionary yaitu;

"Any act which is calculated to embarrass, hinder or obstruct court in adminstration of justice or which is calculated to lessen its authority or its dignity. Committed by a person who does any act in willful contravention of its authority or its dignity, or tending to impede or frustate the administration of juctice or by one who, being under the the court's authority as a party to a proceeding there in, willfully disobeys its lawful orders or fails to comply with an undertalking which he has given".18

Contempt of court meliputi setiap perbuatan yang dapat dinilai sebagai sebuah perbuatan yang mempermalukan, merintangi atau menghalangi penyelenggaraan peradilan atau perbuatan-perbuatan lain yang dapat dinilai akan menurunkan kewibawaan atau martabat lembaga pengadilan.

Pengertian Criminal contempt of court merupakan perbuatan yang tidak saja menghormati pengadilan dan proses peradilannya yang bertujuan untuk merintangi, menghalangi, mengganggu jalannya peradilan atau cenderung untuk menyebabkan pengadilan tidak dihormati. ${ }^{19}$

Barda Nawawi Arief mempunyai suatu pandangan dan mengklasifikasikan bentuk-bentuk atau ruang lingkup criminal contempt antara lain:

a) Gangguan di muka atau di dalam ruang sidang pengadilan;

b) Perbuatan-perbuatan untuk mempengaruhi proses peradilan yang tidak memihak;

c) Perbuatan yang memalukan atau menimbulkan skandal bagi pengadilan;

d) Pembalasan terhadap perbuatan-perbuatan yang dilakukan selama proses peradilan berjalan;

e) Pelanggaran oleh pengacara;

Dengan merujuk pada klasifikasi di atas, maka setiap individu yang tidak menaati peraturan tentang tata tertib persidangan dapat berujung kepada penuntutan, jika pelanggaran itu merupakan tindak pidana. Pada tahap itulah selain criminal contempt of court, Henry juga memunculkan istilah civil contempt of court yang dipergunakan untuk menggambarkan contempt yang disebabkan ketidakpatuhan terhadap perintah yang diberikan oleh pengadilan perdata. Umumnya, pelanggaran dalam civil contempt ini disebabkan kegagalan dari salah satu pihak yang berperkara untuk melakukan atau melaksanakan perintah pengadilan guna manfaat atau keuntungan pihak lainnya.

\footnotetext{
${ }^{18}$ Henry Black Cambell, Black's Law Dictionary, St. Paul, MINN West Publishing co, hlm. 390.

${ }^{19}$ Ibid.
} 
Contempt yang paling seringkali terjadi dalam perkara perdata, adalah pengabaian terhadap perintah putusan pengadilan, baik yang berupa perintah positif seperti; perintah untuk mengosongkan suatu rumah yang disita oleh bank, maupun perintah negatif seperti larangan bagi para tertentu untuk menjual sebidang tanah yang sedang disengketakan.

Pengaturan tentang contempt of court yang demikian tidak lain dimaksudkan untuk membela supremasi hukum agar proses peradilan dapat dilaksanakan dengan sewajarnya dan adil, tanpa diganggu, dipengaruhi atau dirongrong oleh pihak-pihak lain, baik selama proses peradilan berlangsung di pengadilan maupun diluar gedung pengadilan. ${ }^{20}$

Hal ini sejalan dengan UU No. 14 Tahun 1985 tentang Mahkamah Agung butir 4 alinea ke-4, yang secara eksplisit menyebutkan istilah contempt of court:

"Selanjutnya untuk dapat lebih menjamin terciptanya suasana yang sebaik-baiknya bagi penyelenggara peradilan guna menegakkan hukum dan keadilan berdasarkan Pancasila, maka perlu dibuat suatu undang-undang yang mengatur penindakan terhadap perbuatan, tingkah laku, sikap dan/atau ucapan yang dapat merendahkan dan merongrong kewibawaan, martabat dan kehormatan badan peradilan yang dikenal sebagai contempt of court".

Puncak adanya kewibawaan hakim tidak lain adalah penghormatan terhadap putusannya. Dalam sebuah adagium bahkan dikatakan bahwa; "Res Judicata Pro Veritate habetur, yang artinya putusan hakim harus dianggap benar. Jika ditinjau secara lebih mendalam, maka pesan utama dari adagium tersebut adalah ketaatan dan penghormatan terhadap pengadilan yang ditandai dengan pelaksanaan perintah putusan pengadilan.

Dalam konteks sistem hukum Indonesia, ada beberapa pasal dalam KUHP yang dapat digunakan untuk menjerat pihak yang melakukan pembangkangan terhadap perintah putusan pengadilan. Contohmya, dalam Pasal 212 KUHP mengatur perihal perlawanan terhadap pejabat yang sedang menjalankan tugasnya. Pasal tersebut berbunyi sebagai berikut;

“Barangsiapa dengan kekerasan atau ancaman kekerasan melawan seorang pejabat yang sedang menjalankan tugas yang sah, atau orang yang menurut kewajiban undangundang atau atas permintaan pejabat memberi pertolongan kepadanya, diancam karena melawan pejabat, dengan pidana penjara paling lama satu tahun empat bulan atau pidana denda paling banyak Rp $4.500^{\prime \prime}$.

Kemudian, Pasal 216 ayat (1) KUHP menyebutkan:

Barangsiapa dengan sengaja tidak menuruti perintah atau permintaan yang dilakukan menurut undang-undang oleh pejabat yang tugasnya mengawasi sesuatu, atau oleh pejabat berdasarkan tugasnya, demikian pula yang diberi kuasa untuk mengusut atau memeriksa tindak pidana; demikian pula barangsiapa dengan sengaja mencegah, menghalang-halangi atau menggagalkan tindakan guna menjalankan ketentuan undang-undang yang dilakukan oleh salah seorang pejabat tersebut, diancam dengan

${ }^{20}$ MAPPI (Masyarakat Pemantau Peradilan Indonesia) Fakultas Hukum Indonesia, Suatu Tinjauan tentang Contempt of Court, (www.pemantauperadilan.com $)$, hal. 2 


\section{Yoyo Arifardhani}

pidana penjara paling lama empat bulan dua minggu atau pidana denda paling banyak Rp 9.000.

Pasal 212 dan Pasal 217 KUHP itu sangat jarang diterapkan untuk memaksa pihak yang mengabaikan putusan pengadilan. Salah satu alasan yang bisa dijadikan alasan adalah bahwa pengaturan tersebut masih bersifat sangat umum dan sumir, sehingga para penegak hukum pun merasa riskan menjadi obyek kritik masyarakat dalam hal mengkriminalisasikan perbuatan pengabaian terhadap putusan pengadilan.

Perbaikan sistem eksekusi putusan pengadilan tentu memerlukan peran dari semua pihak termasuk Pemerintah dalam menciptakan regulasi yang lebih jelas dan lengkap terkait dengan eksekusi. Namun begitu, penyelesaian perkara khususnya perkara perdata sangat membutuhkan adanya tindakan tegas terhadap perilaku pengabaian perintah putusan pengadilan.

Untuk mengatasi dilematika tersebut, penulis hendak mengajukan solusi sementara, yakni pengaturan kriminalisasi terhadap perbuatan pengabaian perintah putusan pengadilan melalui peraturan mahkamah agung (Perma). Dalam hal ini, perma tersebut hendaknya memberikan perintah kepada aparat kepolisian untuk memproses perbuatan pengabaian terhadap putusan pengadilan dengan menggunakan Pasal 212 dan Pasal 217 KUHP tersebut.

Hal ini tentu sangatlah logis mengingat pranata hukum acara perdata memiliki keterbatasan dalam hal pihak yang hendak yang kalah melakukan perlawanan secara fisik. Selain itu, pengaturan demikian juga sejalan dengan prinsip hukum pidana sebagai ultimum remedium. Dengan cara demikian, putusan pengadilan akan lebih efektif dan memiliki daya paksa yang sebenarnya.

\section{KESIMPULAN}

Berdasarkan ulasan dalam pembahasan di atas, maka dapat ditari beberapa kesimpulan sebagai berikut:

1. Pelaksanaan eksekusi putusan pengadilan ini tidak mudah dilaksanakan karena menghadapi beberapa kendala Apabila termohon eksekusi tetap bertahan diatas obyek sengketa dalam arti tidak mau menyerahkan kepada pemohon eksekusi, maka dapat mengakibatkan ditangguhnya proses pelaksanaan eksekusi. Selain itu, tidak ada jaminan bahwa setelah diputusnya permohonan eksekusi, termohon eksekusi akan melaksanakan perintah pengadilan.

2. Upaya paksa untuk melaksanakan putusan pengadilan melalui pranata eksekusi putusan senyatanya kurang berdaya manakala termohon tetap bersikukuh untuk mengabaikan putusan pengadilan. Kedudukan termohon eksekusi pun kian kuat manakala penolakannya mendapat dukungan oleh masyarakat setempat. Bahkan ada juga yang secara sengaja menyewa preman agar putusan pengadilan tidak bisa dieksekusi sebagaimana mestinya. 


\section{REFERENSI:}

\section{Buku-Buku}

Adityo Wahyu Wikanto, Safrudin Yudowibowo, Harjono, “Eksekusi Riil dalam Perkara Perdata Tentang Pengosongan Tanah dan Bangunan Rumah", Jurnal Verstek, Vol.2, No. 2, 2014.

Alfeus Jebabun dkk, 2018 Initial AssesmentProblems of court decision enforcment system in indonesia", Lembaga Kajian \& Advokasi Independensi Peradilan, Jakarta.

Ali, Chaidir, 1983, Yurisprudensi Hukum AcaraPerdata Indonesia, Armico, Bandung.

Ali, Chaidir, 1993, Perlawanan Terhadap Eksekusi Gross Akta Serta Putusan Pengadilan dan Arbitrase dan Hukum Eksekusi, Citra Adiya Bakti, Bandung.

Ali, Chaidir, 1997, Beberapa Tinjauan Mengenai Sistem Peradilan dan Penyelesaian Sengketa, Citra Aditya Bakti, Bandung.

Henry Black Cambell, Black's Law Dictionary, St. Paul, MINN West Publishing co.

Himpunan SEMA dan PERMA, Februari 1999, Jakarta: MARI.

Jurnal Bisnis Volume 18 Maret 2002.

M. Yahya Harahap, 2005, Sekitar Acara dan Hukum Perdata Agama, dalam PT. Tananusa, Jakarta.

M. Yahya Harahap, 1989, Ruang Lingkup Eksekusi Bidang Perdata, PT. Gramedia, Jakarta.

M. Yahya Harahap, 2005, Hukum Acara Perdata Tentang Tentang Gugatan, Persidangan, Penyitaan, Pembuktian, Dan Putusan Pengadilan, Cetakan Ketiga, Jakarta.

MAPPI (Masyarakat Pemantau Peradilan Indonesia) Fakultas Hukum Indonesia, Suatu Tinjauan tentang Contempt of Court, diunduh dari www.pemantauperadilan.com.

Mukri, S.G.; Aji, A.M.; Yunus, N.R. (2016). "Implementation of Religious Education in the Constitution of the Republic of Indonesia," Salam: Sosial dan Budaya Syar-i, Volume 3 No. 3.

Mukri, S.G.; Aji, A.M.; Yunus, N.R. (2017). Relation of Religion, Economy, and Constitution In The Structure of State Life, STAATSRECHT: Indonesian Constitutional Law Journal, Volume 1, No. 1.

Peraturan Mahkamah Agung No. 2 Tahun 2015 Tentang Tata Cara Penyelesaian Gugatan Sederhana.

Sita Eksekusi; Praktek Kejurusitaan Pengadilan, PT. Tatanusa, Jakarta.

Tim Riset dan Publikasi, "Menuju Pelaksanaan Eksekusi Putusan Perdata yang Efektif Analisis Data Katadata" artikel diunduh dari https://katadata.co.id/timrisetdanpublikasi/analisisdata/5e9a57af9a822/me 


\section{Yoyo Arifardhani}

nuju-pelaksanaan-eksekusi-putusan-perdata-yang-efektif, Pukul 10.57 WIB, 13 April 2021.

Yunus, N.R.; Anggraeni, RR Dewi.; Rezki, Annissa. (2019). "The Application of Legal Policy Theory and its relationship with Rechtsidee Theory to realize Welfare State," 'Adalah, Volume 3, No. 1. 